\title{
5271 SAYILI CEZA MUHAKEMESİ KANUNU'NDA BASİT ARAMA (ADLİ ARAMA)
}

\author{
Search Constituted in The Criminal Procedure Code Numbered 5271 \\ (Judicial Search)
}

Doç. Dr. Serap KESKİN-KIZİROĞLU*

I- GİRIŞ, II- ADLİ ARAMA ÇEŞiTLERİ, A- AMACINA GÖRE ARAMA ÇEŞITLLERI, a- Yakalama Araması, b- Delil Araması, BARAMAYA TABİ KISSiYYE GÖRE ARAMA ÇEŞITTLERI, a- Şüpheli veya Sanık Nezdinde Arama, b- Diğer Kişiler Nezdinde Arama, cAvukatın Aranması, C- ARAMANIN KONUSUNA GÖRE ARAMA ÇEŞITLERI, a- Üst Araması, b- Eşyada Arama, c- Konutta Arama, dİşyerinde veya Aramaya Tabi Kişiye Ait Diğer Yerlerde Arama, IIIADLİ ARAMANIN KOŞULLARI, A-MADDİ KOŞULLAR, a- Şüpheli Veya Sanık Nezdinde Aramadaki Maddi Koşullar, b- Diğer Kişiler Nezdinde Aramada Maddi Koşullar, B- KARAR KOŞULU, a- Arama Kararında Bulunması Gereken Hususlar, b- Arama Kararı veya Emri Olmadan Arama Yapılabilecek Durumlar, ba) Hakkında tutuklama kararı veya yakalama emri veya zorla getirme kararı bulunan kiși ile hakkında

\footnotetext{
* Maltepe Üniversitesi Hukuk Fakültesi Ceza ve Ceza Usul Hukuku Anabilim Dalı Öğretim Üyesi - İstanbul Üniversitesi Hukuk Fakültesi Ceza ve Ceza Usul Hukuku Anabilim Dalı Emekli Öğretim Üyesi.
} 
gıyabi tutuklama kararı verilen kaçak yakalandığında üstünde yapılacak aramada karar veya yazılı emir gerekmez.(Yön.md.8/a), bb) Hakim kararı veya Cumhuriyet Savcisının yazılı emri ile veya kolluk tarafindan doğrudan yakalanan kişinin, kendisine, başkalarına veya yakalama işlemini yapan kolluk görevlilerine zarar vermesini önlemek amaciyla yapılacak kaba üst aramasında karar veya yazılı emir gerekmez.(Yön.md.8/b), bc)Gözaltına alınan kişinin, nezarethaneye konmadan önce yapılan üst aramasinda karar veya yazılı emir gerekmez.(Yön.md.8/c), bd) Herhangi bir sebeple hukuka uygun şekilde yakalandıktan sonra kolluk güçlerinin elinden kaçmakta olan kişilerin veya işlenmekte olan veya henüz işlenmiş olan veya pek az önce işlendiğini gösteren belirtilerin olduğu suçun failinin yakalanması amacıyla takibi sırasında girdikleri araç, bina ve eklentilerinde yakalanması amaciyla yapılacak aramalarda karar veya emir gerekmez.(Yön.md.8/d), be)Kaçakçılıkla Mücadele Kanunu'na göre karar veya yazılı emrin aranmayacağı durumlar.(Yön.md.8/e), bf)Hukuka uygunluk nedenlerinin varlığında karar veya emir gerekmez.(Yön.md.8/f), bg)Suçun işlendiği kamuya açık alanda olay yeri incelemesi için karar veya emir gerekmez.(Yön.md.9), C- ADLI ARAMANIN ZAMANI, D- ARAMADA HAZIR BULUNMASI GEREKENLER, a- Hazır Bulunabilecek Kişiler, b- Hazır Bulunması Zorunlu Kişiler, E- ARAMANIN SONLANDIRILMASI, FKANUNYOLU

\section{ÖZET}

Çalışma, 01.Haziran.2005 tarihinde yürürlüğe giren 5271 sayılı Ceza Muhakemesi Kanunu çerçevesinde Türk Ceza Muhakemesi Hukuku'nda adli arama koruma tedbirini mercek altına almıştır. Adli arama koruma tedbiri öncelikle, amacına, aramaya tabi kişiye ve konusuna göre çeşitlere ayrılmış ve bu başlıklar altında, yakalama araması, delil araması, şüpheli veya sanık nezdinde arama ile diğer kişiler nezdinde arama ve avukatın aranması konuları ile üst araması, eşyada arama, konutta ve işyerinde arama konuları incelenmiştir. Devamla, adli aramanın koşulları, maddi koşullar ve karar koşulu olarak iki alt başlık altında çalışılmış; karar koşulu inceleme konusu yapılırken adli aramada karar veya emir 
koşulunun aranmadığı haller de tartışılmıştır. Adli aramanın hangi zaman diliminde yapılabileceği, adli aramanın nasıl sonlandırılacağı ve nihayet bir Ceza Muhakemesi Hukuku işlemi olan adli arama işlemine karşı kanunyolu, çalışmanın diğer konu başlıklarını oluşturmuştur.

Anahtar Kelimeler: Adli Arama, Avukatın Aranmas1, Karar Koşulu, İşyerinde Arama, Aramada Kanunyolu

\section{ABSTRACT}

This study examines the judicial search measure that is one of the measures of protection of evidence in accordance with the Criminal Procedure Code, Law 5271, that came into force on 01 June 2005. First, the topic of judicial search is separated into divisions according to the purpose, concept and the person who is to be subject to the search. Under these divisions, the concepts of search incident to arrest, search of evidence, search related to the suspect or accused, search related to the other persons and the search of lawyer as well as the concepts of body search, search of the belongings, search in the dwelling, and business place are examined. The conditions of judicial search are studied under two categories: substantive conditions and condition of warrant. Those cases which do not require a search warrant or search order are also examined under the topic of the conditions of the judicial search warrant. The other topics discussed in this study are the time of the judicial search, the ways to terminate the judicial search, and finally the legal remedy against a judicial search proceeding under the Criminal Procedure Law.

Keywords: Judicial search, search of lawyer, condition of warrant, search at business place, legal remedy in search

\section{I- GIRIŞ}

Suç işlendiği şüphesi üzerine, şüpheyi ortadan kaldırmak için suçun işlenip işlenmediğini ve suçlunun kim olduğunu kesin olarak ortaya çıkarabilmek amacıyla ceza muhakemesinde temel hak ve özgürlüklere müdahale niteliği taşıyan koruma tedbirlerine başvurmak kaçınılmazdır. Ancak, hukuk devletinde temel hak ve özgürlüklerin, özlerine 
dokunulmaksızın yalnızca Anayasa'nın ilgili maddelerinde belirtilen sebeplere bağlı olarak ve ancak kanunla sinırlanabileceği de Türkiye Cumhuriyeti Anayasası'nın 13.maddesinde yer alan bir anayasal zorunluluktur. Yasal sinırlamalar ise Anayasa'nın sözüne ve ruhuna, demokratik toplum düzeninin ve laik Cumhuriyet'in gereklerine ve ölçülülük ilkesine aykırı olamayacaktır. (TC.Anayasası md.13)

$\mathrm{Bu}$ çerçevede arama ve beraberinde elkoyma tedbiri, Anayasamızın 'Temel Haklar ve Ödevleri' düzenleyen 'İkinci Kısım'da, 'Kişinin Hakları ve Ödevlerini' içeren 'İkinci Bölüm'de, kişinin özel hayatın gizliliği ve korunması hakkı ile ilgilidir ve bu hakka müdahale edici niteliktedir.

Anayasa'mızın 20.maddesine göre kişinin özel yaşamının gizliliği hakk1 ile Anayasa'mızın 21. maddesine göre kişinin konut dokunulmazlığı hakları yalnızca şu nedenlerle sınırlanabilir:

a- Ulusal güvenlik

b- Kamu düzeni

c- Suç işlenmesinin önlenmesi

d- Genel sağlığın korunması

e- Genel ahlakın korunmas1

f- Başkalarının hak ve özgürlüklerinin korunması!

$\mathrm{Bu}$ nedenlerden biri veya birkaçına bağlı olarak usulüne göre verilmiş yargıç kararı olmadıkça; yine bu nedenlere bağlı olarak gecikmesinde sakınca bulunan hallerde de kanunla yetkili kılınmış merciin yazılı emri bulunmadıkça kimsenin üstü, özel kağıtları, eşyası aranamayacağı ve bunlara el konulamayacağı gibi, kimsenin konutuna girilemez, burada arama yapılamaz ve buradaki eşyaya elkonulamaz. Yetkili merciin kararı yirmi dört saat içinde görevli yargıcın onayına sunulur. Yargıç, kararını elkoymadan itibaren kırk sekiz saat içinde açıklar; aksi halde elkoyma kendiliğinden kalkar. (TC.Anayasası md.20,21)

Anayasa'mızın 90/son maddesine göre usulüne göre yürürlüğe konulmuş uluslararası sözleşmeler kanun hükmünde olup, bunlardan 
temel hak ve özgürlüklere ilişkin olanlarla kanunların aynı konuda farklı hükümler içermesi durumunda uluslararası sözleşme hükmünün esas alınacağı da bilinmelidir.

Türk Hukuk Düzeninin de bir parçası olan Birleşmiş Milletler İnsan Hakları Evrensel Bildirgesi'nin 12. maddesi ile Birleşmiş Milletler Medeni ve Siyasal Haklar Sözleşmesi'nin 17. maddesi, kişinin özel ve aile yaşamına, konutuna ve haberleşmesine keyfi veya hukuka aykırı olarak müdahale edilemeyeceği ve kişinin onuru veya itibarının hukuka aykırı müdahalelere maruz bırakılamayacağı; herkesin bu tür saldırı veya müdahalelere karşı hukuken korunma hakkına sahip olduğu hükmünü taşımaktadır.

Aynı şekilde, 'Avrupa İnsan Hakları Mahkemesi", adı altında bir yargılama organını da kuran Avrupa Konseyi Avrupa İnsan Hakları Sözleşmesi'nin 8. maddesi de özel yaşamın ve aile yaşamının korunması hakkını düzenlemektedir. Bu madde hükmüne göre, herkes özel ve aile yaşamına, konutuna ve yazışmalarına saygı gösterilmesi hakkına sahiptir. $\mathrm{Bu}$ hakların kullanılmasına resmi bir makamın müdahalesi, demokratik bir toplumda ancak;

a) ulusal güvenlik

b) kamu güvenliği

c) ülkenin ekonomik gönenci

d) düzenin korunmas1

e) suçların önlenmesi

f) sağlığın korunması

g) ahlakın korunmas1

h) başkasının hak ve özgürlüklerinin korunması için, zorunlu bulunduğu ölçüde ve kanunla düzenlenmesi koşuluyla olabilir.

\section{II- ADLİ ARAMA ÇEŞITTLERI}

Adli arama, müsadereye tabi ya da ispat değeri taşıyan ama ortada bulunmayıp saklı olan eşyanın, bulunup ele geçirilmesi ile yine ele geçirilemeyen şüpheli veya sanığın bulunup ele geçirilebilmesi için 
yapılan bir Ceza Muhakemesi Hukuku işlemidir. ${ }^{1} 5271$ sayılı CMK.'da aramaya ilişkin hükümler Kanun'un 116-122. maddeleri arasında düzenlenmiştir. Adli arama, aramanın amacına, aramaya tabi kişinin ceza muhakemesindeki sıfatına ve aramanın konusuna göre ayırımlara tutulabilir.

\section{A- AMACINA GÖRE ARAMA ÇEŞITLERİ}

Adli arama, amacına göre ya yakalama araması ya da delil aramasidır. $^{2}$

\section{a- Yakalama Araması}

Arama, şüpheli veya sanığın yakalanması amacıyla yapılıyorsa söz konusu olan yakalama aramasıdır.

\section{b- Delil Araması}

Arama, suç delillerinin elde edilebilmesi amacıyla yapılıyorsa söz konusu olan delil aramasıdır.

\section{B- ARAMAYA TABİ KISŞIYYE GÖRE ARAMA ÇEŞITLERİ}

\section{a- Şüpheli veya Sanık Nezdinde Arama}

Ceza Muhakemesi Hukuku'nda şüpheli veya sanık konumunda bulunan bir kişi ile şüpheli veya sanık olmayan diğer bir kişinin koruma tedbirleri dolayısıyla temel hak ve özgürlüklerine müdahale koşulları farklı düzenlenebilir. Arama koruma tedbirinde de bu durumu görmekteyiz.

Ceza Muhakemesi Kanunu'muza göre şüpheli, soruşturma evresinde suç şüphesi altında bulunan kişiyi, sanık ise kovuşturma evresinde suç şüphesi altında bulunan kişiyi tanımlar.(CMK.md.2) Suç şüphesi altında bulunmayan bir kişinin yapılan ceza muhakemesi işi dolayısıyla temel hak ve özgürlüklerine müdahalede, şüpheli veya sanığa göre daha sıkı koşullara tabi tutulması doğaldır. Bu nedenle Ceza Muhakemesi Kanunu,

\footnotetext{
${ }^{1}$ Nurullah Kunter/Feridun Yenisey/Ayșe Nuhoğlu, Muhakeme Hukuku Dalı Olarak Ceza Muhakemesi Hukuku, Beta Yayınevi İstanbul, 15.Bas1, Kasım 2006, No.59.3, s.897.

2 Delil aramasına, "araştırma araması" da denmektedir. Bkz. Kunter/Yenisey/Nuhoğlu, age., No.59.4-V, s.905.
} 
116. maddesinde şüpheli veya sanıkla ilgili aramayı ayrı, 117. maddesinde ise diğer kişilerle ilgili aramayı ayrı düzenlemiştir.

CMK.'muzun 116. maddesine göre 'yakalanabileceği veya suç delillerinin elde edilebileceği hususunda makul şüphe varsa; şüphelinin veya sanığın üstü, eşyası, konutu, işyeri veya ona ait diğer yerler aranabilir.'

\section{b- Diğer Kişiler Nezdinde Arama}

CMK.'muzun 117.maddesinde düzenlenmiştir. Buna göre '(1)şüphelinin veya sanığın yakalanabilmesi veya suç delillerinin elde edilebilmesi amacıyla, diğer bir kişinin de üstü, eşyası, konutu, işyeri veya ona ait diğer yerler aranabilir.

(2)Bu hallerde arama yapılması, aranan kişinin veya suçun delillerinin belirtilen yerlerde bulunduğunun kabul edilebilmesine olanak sağlayan olayların varlığına bağlıdır.

(3) $\mathrm{Bu}$ sinırlama, şüphelinin veya sanığın bulunduğu yerler ile izlendiği sırada girdiği yerler hakkında geçerli değildir.'

\section{c- Avukatın Aranması}

Avukatın aranması konusunda hem CMK.'nun 130.maddesinde hem de 1136 sayılı Avukatlık Kanunu'nun 58.maddesinde hüküm vardır. Avukatlık Kanunu'nun, 23.01.2008 tarih ve 5728 say1lı Kanun'un 331.maddesiyle değişik 58.maddesine göre:

Avukatların, avukatlık veya Türkiye Barolar Birliği ya da baroların organlarındaki görevlerinden doğan veya görev sırasında işledikleri suçlardan dolayı haklarında soruşturma, Adalet Bakanlığı'nın vereceği izin üzerine, suçun işlendiği yer Cumhuriyet Savcısı tarafından yapılır. Avukat yazıhaneleri ve konutları ancak mahkeme kararı ile ve kararda belirtilen olayla ilgili olarak Cumhuriyet Savcısı denetiminde ve baro temsilcisinin katılımı ile aranabilir. Ağır ceza mahkemesinin görev alanına giren bir suçtan dolayı suçüstü hali dışında avukatın üzeri aranamaz.

Görüldüğü üzere, Avukatlık Kanunu, avukatın görevinden doğan veya görevi sırasında işlediği suçtan dolayı arama işlemini özel 
düzenlemeye tabi tutmuştur. Bu durumda uygulanacak hüküm Avukatlık Kanunu'nun 58.maddesi hükmüdür. Bu hüküm gereğince, avukatın görevinden doğan veya görevi sırasında işlediği suçtan dolayı arama işlemindeki özel norm CMK.' daki düzenlemeden farklı olarak avukatın konutunda aramayı ve üst aramasını da kapsamaktadır.

CMK.'nun, 'Avukat bürolarında arama, elkoyma ve postada elkoyma' başlığını taşıyan 130.maddesindeki hüküm ise Avukatlık Kanunu'nun 58.maddesinden farklı olarak avukatın görevinden doğmayan veya görevi sırasında işlenmeyen adi suçları ile ilgilidir. ${ }^{3} \mathrm{Bu}$ nedenle avukatın konutunu değil yalnızca bürosunu kapsayan bir düzenleme taşır. Aynı şekilde avukatın söz konusu adi suçtan dolayı üst aramasında da özel düzenleme yoktur. CMK.'nun 130.maddesine göre de avukat büroları ancak mahkeme kararı ile ve kararda belirtilen olayla ilgili olarak Cumhuriyet Savcısının denetiminde aranabilir. Baro başkanı veya onu temsil eden bir avukat aramada hazır bulundurulur.

Her iki Yasada da arama işleminin mahkeme kararı ile yapılabileceği ifade edilmekteyse de soruşturma evresinde henüz mahkeme makamı bulunmadığından söz konusu yargılama makamı doğal olarak sulh ceza yargıçlı̆̆ı olacaktır. ${ }^{4}$

\section{C- ARAMANIN KONUSUNA GÖRE ARAMA ÇEŞITLERİ}

\section{a- Üst Araması}

Üst aramas1, beden muayenesine dönüşmeyecek tarzda kişinin üzerinde yapılan arama olup, aynı zamanda kişinin beden dokunulmazlığına da dokunan bir arama türüdür. Üst araması yapılırken kişinin üzerinde taşıdığ 1 giysilerde arama yapıldığı gibi, kişinin bu giysilerin altında çıplak bedeninde bir şey bulunup bulunmadığının gözle tespiti de CMK. düzenlemesine göre üst araması kapsamındadır. ${ }^{5} \mathrm{Bu}$ bağlamda CMK.'nda şüpheli veya sanığın dış beden muayenesinin, mağdurun dış beden muayenesinden farklı olarak arama hükümlerine

\footnotetext{
${ }^{3}$ Nur Centel/Hamide Zafer, Ceza Muhakemesi Hukuku, Beta Basım İstanbul, Ocak 2008, 5.B, s.395.

${ }^{4}$ Centel/Zafer, age., s.395.

5 Aynı yönde Bahri Öztürk-Mustafa Ruhan Erdem, Uygulamalı Ceza Muhakemesi Hukuku, Seçkin Yayınevi Ankara,12.Bası, Kasım 2008, s. 591.
} 
bırakılmış olduğu da belirtilmelidir. Ancak, cinsel organlar veya anüs bölgesinde yapılan muayenenin de yasa gereği iç beden muayenesi sayıldığı bilinmelidir. (CMK.md.75/4)

Üst araması, kişinin cinsiyetinde bulunan görevli tarafından yapılır. (Adli ve Önleme Aramaları Yönetmeliği md.28)

\section{b- Eşyada Arama}

Aramaya tabi kişinin zilyetliğinde bulunan her türlü taşınır malda yapılan aramadır.

\section{c- Konutta Arama}

Konuttan maksat ikametgâh değildir. Konut, kişinin özel yaşam alanı olarak belirlediği dıştan anlaşılan, burada sürekli veya geçici olarak oturulan veya kalınan yerdir. Bu bağlamda kişinin konakladığı bir otel odası konut sayılacağı gibi, çadır, karavan, tekne gibi yaşam alanları da konut olarak kullanıldıkları takdirde konut sayılırlar.

\section{d- İşyerinde veya Aramaya Tabi Kişiye Ait Diğer Yerlerde Arama}

Her ne kadar Anayasa'da konuttan başka, işyeri ve diğer yerlerde arama ve el koymaya ilişkin bir içerik yoksa da, kişinin, genel yer (umumi yer) niteliği taşımayan işyeri ve diğer kapalı taşınmaz alanları da temel hak olan kişinin özel yaşamının dokunulmazlığ ile ilgili alanlardır. $\mathrm{Bu}$ nedenle Anayasa'mızın işyerini ve kişiye ait diğer kapalı taşınmaz alanları koruma kapsamı dışında tuttuğu söylenemeyecektir. Kamuya veya genele açık işyeri, her zaman genel yer niteliğini de beraberinde taşımaz. Kamuya açık işyeri, açık bir rızaya gerek duyulmaksızın girilmesi mutat olan yer olup, bu bağlamda konut dokunulmazlığını ihlal suçu açısından önem taşır.

Nitekim konut dokunulmazlığını ihlal suçunun düzenlendiği Türk Ceza Kanunu'nun 116/2. maddesi de, açık bir rızaya gerek duyulmaksızın girilmesi mutat olan yerlerde konut dokunulmazlığının ihlali suçunu kabul etmezken, açık bir rızaya gerek duyulmaksızın girilmesi mutat olan yerler dışında kalan işyerleri ve eklentilerine karşı da konut dokunulmazlığını ihlal suçunun varlığını kabul etmektedir. Bu bağlamda, kanaatimizce kamuya açık işyeri veya diğer yerler, hiçbir işi olmayıp, 
yalnızca bakınmak için bile olsa, isteyenin elini kolunu sallayarak girip, orada bulunabildiği ve istediği şeye dokunup, araştırıp, bakabildiği yerlerdir. Ancak, Ceza Muhakemesi Hukuku'nda arama işlemi açısından, CMK. konut ile işyerini bir tutmuş, aramaya tabi kişiye ait diğer yerler açısından ise bu yerin kamuya açık kapalı alan olup olmamasına göre aşağıda inceleyeceğimiz farklı bir düzenleme yapmıştır.

Adli arama işlemi açısından, CMK.'nun 116. ve 117. maddeleri bağlamında kişinin işyeri ve ona ait yerlerde de tıpkı konutta olduğu gibi arama işlemi yapılabilecektir. Ancak, arama işleminin koşullarından karar koşulu açısından konut ve işyeri dışında kalan yerin kamuya açık olup olmaması önem taşımaktadır.

İşyeri, avukat bürosu ise CMK.'nun 130.maddesindeki özel düzenlemeye tabi olur. Bu noktada 1136 say1lı Avukatlık Kanunu'nun 58.maddesinin de göz önünde tutulması gerekir.

\section{III- ADLİ ARAMANIN KOŞULLARI}

\section{A-MADDİ KOŞULLAR}

\section{a- Şüpheli Veya Sanık Nezdinde Aramadaki Maddi Koşullar}

Yakalama aramasında, şüpheli veya sanığın eşyasında, konutunda, işyerinde veya ona ait diğer yerlerde arama koruma tedbirinin uygulanabilmesi için, şüpheli veya sanığın bu yerlerde yakalanabileceğine dair makul şüpheyi temellendiren somut verilerin varlığ1 yeterlidir. Bunun gibi delil aramasında da suç delillerinin şüpheli veya sanığın üstünden, eşyasından, konutundan, işyerinden veya ona ait diğer yerlerden elde edilebileceğine dair makul şüphe varsa arama koruma tedbirine başvurulabilecektir.

Makul şüphe, Adli ve Önleme Aramaları Yönetmeliği'nin 6. maddesine göre, hayatın akışına göre somut olaylar karşısında genellikle duyulan şüphedir. Bu cümleden anlaşılması gereken, söz konusu somut durum veya olay karşısında genel deneyim kurallarına göre genellikle ortaya çıkan şüphedir. Makul şüphe, aramanın yapılacağ 1 zaman, yer ve ilgili kişinin veya onunla birlikte olanların davranış, tutum ve biçimleri, kolluk memurunun taşındığından şüphe ettiği eşyanın niteliği gibi sebepler göz önünde bulundurularak belirlenir. Makul şüphede, ihbar 
veya şikâyeti destekleyen belirtilerin var olması gerekir. Arama sonunda belirli bir şeyin bulunacağını veya belirli bir kişinin yakalanacağını öngörmeyi gerektiren somut olgular var olmalıdır. Şüphenin her durumda somut olgulara dayanması gerekir.

Kanaatimizce şüpheli veya sanık nezdinde delil aramasında, arama kararı verebilmek için, aranacak suç delillerinin neler olduğunun somutlaştırılmış şekilde teker teker belirlenmiş olması gerekli değildir. Aramaya tabi kişi şüpheli veya sanık ise, neler olduğu önceden kesin olarak bilinmese dahi genel olarak suçu ve suçluyu ispata yarayacak delil değerini taşıyabilecek bulguların, onun üstünde, eşyasında, konutunda vs.de bulunabileceğine dair makul şüphenin varlığı yeterlidir. Aynı husus yakalama araması bakımından da geçerlidir. Şüpheli veya sanık nezdinde bu amaçla arama koruma tedbirine başvurulabilmesi için, makul şüpheyi temellendirmekten daha fazla, şüpheli veya sanığın söz konusu yerlerde bulunduğunun kabul edilebilmesine olanak sağlayan yeterli derecede somut bulguların varlığı aranmaz; bu husustaki makul şüphe yeterli olur.

\section{b- Diğer Kişiler Nezdinde Aramada Maddi Koşullar}

Diğer kişiler nezdinde gerek yakalama araması, gerekse delil araması yapabilmek için, şüpheli veya sanığın söz konusu yerlerde yakalanabileceğine dair makul şüphe yeterli olmadığı gibi, delil aramasında da genel olarak suç delillerinin bu yerlerden elde edilebileceğine dair makul şüphe yeterli değildir. ${ }^{6}$

CMK. 116. maddesinde şüpheli veya sanıkla ilgili olarak açıkça makul şüpheden söz etmişken, diğer kişilerle ilgili aramayı düzenleyen 117. maddesi hükmünde makul şüphe kavramına yer vermeyip, tam aksine üçüncü kişi nezdinde arama yapılabilmesini, aranılan kişinin veya delilin burada bulunduğunun kabul edilebilmesine olanak sağlayan olayların varlığına bağlamıştır.

CMK.'nun 117. maddesine göre, şüphelinin veya sanığın yakalanabilmesi veya suç delillerinin elde edilebilmesi amacıla, diğer bir kişinin üstünde, eşyasında, konutunda, işyerinde veya ona ait diğer

${ }^{6}$ Aynı görüşte Cumhur Şahin, Ceza Muhakemesi Hukuku I, Seçkin Yayıncılık-Ankara 2007, s.242; Faruk Turhan, Ceza Muhakemesi Hukuku, Asil Yayın Dağıtım Ankara, 2006, s.241. 
yerlerde arama yapılabilmesi, aranılan kişinin veya suçun delillerinin bu yerlerde bulunduğunun kabul edilebilmesine olanak sağlayan olayların varlığına bağlıdır.

$\mathrm{Bu}$ nedenle yakalama aramasında, diğer bir kişi nezdinde arama koruma tedbirine başvurabilmek için, şüpheli veya sanığın, makul şüphenin ötesinde somut olarak bu kişi nezdinde yakalanabileceğini gösteren yeterli somut bulgular bulunmalıdır; aynı şekilde delil aramasında da suçun delillerinin diğer kişi nezdinde elde edilebileceği kanaatine olanak sağlayan makul şüphenin ötesinde yeterli somut bulgular bulunmalıdır. ${ }^{7} \mathrm{Bu}$ noktada, gerek yakalama aramasında gerekse delil aramasında mutlak kanaat aranmamaktadır. Ancak, şüpheli veya sanık konumunda bulunmayan üçüncü kişide arama koruma tedbirine başvurulabilmesi için makul şüpheyi aşan, aranan şüpheli veya sanığın ya da aranan delilin/delillerin bu kişi nezdinde ele geçirilebileceği düşüncesini haklı gösterebilen yeterli şüpheyi temellendiren somut bulguların varlığı gerekir.

Bunun tek istisnası yakalama aramasında şüphelinin veya sanığın bulunduğu yerler ile izlendiği sırada girdiği yerler hakkındaki aramadadır. Olayın akışına göre gerçekleşen bu gibi durumlarda ayrıca şüphelinin veya sanığın bu yerlerde bulunduğunun kabul edilebilmesine olanak sağlayan başka olaylara gerek yoktur. ${ }^{8}$

Şüpheli veya sanık nezdinde aramadan farklı olarak, üçüncü kişi nezdinde delil araması yapabilmek için, elde edilmek istenen delilin somut olarak ne olduğunun da önceden yeterli şüphe temelinde tespit edilmiş olması gerekir. Bu noktada, neler olduğu önceden kesin olarak bilinmese dahi genel olarak suçu ve suçluyu ispata yarayacak delil değerini taşıyabilecek bulguların, üçüncü kişinin üstünde, eşyasında, konutunda vs.de bulunabileceğine dair makul şüphenin varllğ 1 yeterli değildir.

\footnotetext{
${ }^{7}$ Aynı Görüşte Nevzat Toroslu-Metin Feyzioğlu, Ceza Muhakemesi Hukuku, Savaş Yayınları, Ankara 2006, s.238 .

${ }^{8}$ Toroslu-Feyzioğlu, s.239.
} 


\section{B- KARAR KOŞULU}

Kural olarak arama koruma tedbirine Anayasa'nın 20. ve 21. maddeleri doğrultusunda CMK.'nun 119. maddesi gereğince yargıç karar verir. Ancak Anayasa'nın bu hükümlerine göre gecikmesinde sakınca bulunan hallerde, kanunla yetkili kılınmış merci sıfatıyla, yine CMK.'nun 119. maddesi gereğince Cumhuriyet Savcısının, Cumhuriyet Savcısına ulaşılamayan hallerde ise kolluk amirinin yazılı emri ile kolluk görevlileri arama işlemini yapabileceklerdir. Yazılı emir üzerine arama işleminin, emrin verildiği zamandan itibaren 24 saat içinde, soruşturma evresinde sulh ceza yargıcının, kovuşturma evresinde ise mahkemenin onayına sunulması anayasal zorunluluktur.

Suç şüphesinin öğrenilmesinden iddianamenin kabulüne kadar geçen evreyi ifade eden soruşturma evresinde (CMK.md.2/1e) arama kararını vermeye yetkili yargıç, işlemin yapılacağı yerin sulh ceza yargıcıdır. (CMK.md.162) Özel yetkili ağır ceza mahkemelerinin görev alanına giren suçların soruşturmasında ise yetkili yargıç, bu mahkemenin üyesidir.

İddianamenin kabulünden, hükmün kesinleşmesine kadar geçen evreyi ifade eden kovuşturma evresinde (CMK.md.2/1,f) ise, kanunda bu hususta özel bir düzenleme bulunmadığından, yetkili yargılama makamı yargıçlık makamı olmayıp, mahkeme makamıdır. Acele hallerde mahkeme başkanını da yetkili kılan özel bir düzenleme yoktur. Ceza Muhakemesi Hukuku'nda, eski deyişle son soruşturmada, yeni kanuna göre kovuşturma evresinde yetkili yargılama makamı mahkeme makamıdır. Yargıçlık makamı olarak mahkeme başkanının yetkisi, duruşmayı yönetmek, sanığı sorguya çekmek ve delillerin ikamesini sağlamaktır. (CMK.md.192/1) Duruşmada ilgili olanlardan biri, duruşmanın yönetimine ilişkin olarak mahkeme başkanı tarafından emrolunan bir tedbirin hukuken kabul edilemeyeceğini öne sürerse, mahkeme bu hususta bir karar verir.(CMK.md.192/2)

4926 sayılı ve 10.07.2003 tarihli Kaçakçıllkla Mücadele Kanunu'nun 17/3.maddesinde özel konut ve eklentilerinde hakim kararı olmadıkça arama yapılamaz hükmü yer almışsa da, 5607 sayılı ve 21.03.2007 tarihli Kaçakç1lıkla Mücadele Kanunu öncekini yürürlükten 
kaldırmıştır. (md.25) 5607 sayılı Kaçakçılıkla Mücadele Kanunu'nda ise bu konuda özel bir düzenleme yoktur. Dolayısıyla konut, işyeri ve diğer kapalı alanlarda yapılacak arama ve el koymalarda 5271 sayılı CMK. hükümleri genel kanun olarak uygulanacaktır.

Cumhuriyet Savcısının arama emri verebilmesi için gecikmede sakınca bulunması yeterli iken, kolluk amirinin arama emri verebilmesi için gecikmede sakınca bulunması koşuluna ek olarak Cumhuriyet Savcısına ulaşılamıyor olması koşulu da aranacaktır. Aksi durumda arama emri ve işlemi hukuka aykırı olur. Kolluk amirinin yazılı emri ile yapılan arama işleminin sonuçları derhal Cumhuriyet Başsavcılığına bildirilmek zorundadır.

Kolluk amirinin arama emri verebilmesi için söz konusu koşullara ek olarak, bu arama emrinin konusunun konut, işyeri veya kamuya açı olmayan kapalı alanlar olmaması da aranacaktır. Diğer deyişle konutta, işyerinde ve kamuya açık olmayan kapalı alanlarda arama, yalnızca yargıç kararı veya gecikmesinde sakınca bulunan hallerde Cumhuriyet Savcısının yazılı emri ile yapılabilir.

Yasa koyucu arama işleminde karar koşulu açısından kişinin konutu ile işyerini bir tutmak suretiyle, konuta göre daha açık bir alan olması nedeniyle konut dokunulmazlığını ihlal suçundaki rızayla karıştırmamış; Ceza Muhakemesi Hukuku'nda arama koruma tedbiri açısından özgürlük yararına bir düzenleme yapmıştır. Konut dokunulmazlığını ihlal suçunun düzenlendiği Türk Ceza Kanunu'nun 116/2. maddesine göre, açık bir rızaya gerek duyulmaksızın girilmesi mutat olan işyerleri ve eklentilerine girilmesinde konut dokunulmazlığını ihlal suçu oluşmaz. Fakat bu husus, bu yerlerde arama işlemi yapabilmek için karar veya yazılı emir koşulunu kendiliğinden ortadan kaldırmaz veya zayıflatmaz.

Konut ve işyeri dışındaki kişiye ait alanlarda arama işleminde karar koşulu açısından bu yerin kamuya açık kapalı alan olup olmadığı önemlidir. Kamuya açık olmayan kapalı alanlarda arama işlemi yine yalnızca yargıç kararı veya gecikmesinde sakınca bulunan halde Cumhuriyet Savcısının yazılı emri ile yapılabilir. Kapalı alan, kamuya açık ise bu takdirde anılan koşulla kolluk amirinin yazılı emriyle de o yerde arama işlemi gerçekleştirilebilecektir. Ancak kamuya açık bu 
kapalı alan, herkesin girip çıkabileceği genel yer niteliğindeyse, bu yerde suç işlendiği takdirde orada delil araması yapabilmek için de karar veya emir gerekmez.

Yine, kamuya açık kapalı alanlarda, kamuya açık olmayan kısımlar varsa, kanaatimizce bu kısımlar bakımdan da kolluk amirinin yazılı emri yeterli olmaz.

Adli arama bakımından gecikmesinde sakınca bulunan hal, Adli ve Önleme Aramaları Yönetmeliği'nin 4. maddesine göre, derhal işlem yapılmadığı takdirde suçun iz, eser, emare ve delillerinin kaybolması veya şüphelinin kaçması veya kimliğinin tespit edilememesi ihtimalinin ortaya çıkması ve gerektiğinde yargıçtan karar almak için zaman bulunmaması durumunu ifade etmektedir.

Koşulların varlığında gerek Cumhuriyet Savcısının, gerekse kolluk amirinin vereceği arama emrinin yazılı olması da yasa gereğidir. Kanaatimizce gecikmesinde sakınca bulunan hal özelliği de göz önünde tutulduğunda, kayda geçen telsiz aracıllğıyla verilen sözlü emirde yazılılık koşulu yerine getirilmiş sayılmalıdır.

Bu bağlamda, CMK.'nun 161/3.maddesinde yer alan, Cumhuriyet Savcısının, adli kolluk görevlilerine emirleri yazılı, acele hallerde sözlü olarak verebileceği ve sözlü emrin en kısa sürede yazılı olarak bildirileceği hükmü, anayasal zorunluluk olarak istisnasız yazılı emrin arandığ kabulü Anayasa'ya aykırılık oluşturur. Arama kararı veya yazılı emri olmaksızın arama yapabilmeyi düzenleyen yasal normun tek hukuksal dayanağı, zorunluluk durumudur ki acilliği de beraberinde taşır. Ancak bu koşulla, arama kararı veya emrini aramayan yasal düzenlemenin Anayasa'ya uygunluğu kabul edilebilir.

Yönetmelik gereğince Cumhuriyet Başsavcılıklarınca arama ile ilgili kararları vermek üzere yirmi dört saat süreyle nöbetçi Cumhuriyet Savcıs1 görevlendirilir. (Yön.md.7/son)

\footnotetext{
${ }^{9}$ Kunter/Yenisey/Nuhoğlu, No.59.7-II, s.919.
} 


\section{a- Arama Kararında Bulunması Gereken Hususlar}

CMK.'nun 119/2. maddesine göre arama karar veya emrinde sırasıyla şunların açıkça gösterilmesi zorunludur:

a) Aramanın nedenini oluşturan eylem; bu eylem, suç oluşturduğundan şüphe edinilen ceza soruşturmasına konu olan eylemdir.

b) Üst aramasında aranılacak kişi,

c) Konutta veya diğer bir yerde aramada, aramanın yapılacağ 1 konut veya diğer yerin adresi,

d) Eşyada aramada, aramanın yapılacağı eşya,

e) Arama kararı veya emrinin geçerli olacağı zaman süresi!

b- Arama Kararı veya Emri Olmadan Arama Yapılabilecek Durumlar

5271 sayılı CMK.'nda arama kararı veya arama emri bulunmadan arama yapabilmenin tek yasal dayanağı yalnızca üst aramasıyla ilgili olarak CMK.'nun 90/4. maddesinde bulunmaktadır. Söz konusu madde hükmü emirsiz yakalama yetkisini, diğer deyişle yakalama emri bulunmadığı halde yakalama işleminin yapılabileceği durumları düzenlemektedir. CMK.'nun 90/4.maddesine göre, 'kolluk, yakalandığ 1 sırada kaçmasını, kendisine veya başkalarına zarar vermesini önleyecek tedbirleri aldıktan sonra, yakalanan kişiye kanuni haklarını derhal bildirir.' Kişinin, yakalandığı sırada söz konusu nedenlerle önlem amacıyla üst aramasını yapabilmek için ayrıca karar veya emir aranmaması zorunluluk durumudur ve bu nedenle ilgili yasal düzenleme hukuka uygundur. Aksinin kabulü, eşyanın doğasına aykırı düşer.

$\mathrm{Bu}$ çerçevede 01 Haziran 2005 tarihli 'Adli ve Önleme Aramaları Yönetmeliği'nin 8.maddesi arama kararı veya emri olmadan arama yapılabilecek halleri göstermekte olup, Yönetmeliğin, bu maddesindeki hukuka aykırı bazı düzenlemeleri Danıştay’ca iptal edilmiştir.

Yönetmeliğe göre karar veya emir olmaksızın arama yapılabilecek durumlar şunlardır: 
ba) Hakkında tutuklama kararı veya yakalama emri veya zorla getirme kararı bulunan kişi ile hakkında gıyabi tutuklama kararı verilen kaçak yakalandığında üstünde yapılacak aramada karar veya yazılı emir gerekmez.(Yön.md.8/a)

Yönetmeliğin 8.maddesinin burada değinilen 'a' bendinde, hakkında tutuklama kararı veya yakalama emri veya zorla getirme kararı bulunan kişi ile hakkında gıyabi tutuklama kararı bulunan kaçağın yakalanması amaciyla konutunda, işyerinde, yerleşim yerinde, bunların eklentilerinde ve aracında yapılacak aramada da karar veya emir aranmayacağı hükmü hakkında, İstanbul Barosu'nun açtığı dava sonucunda Danıştay 10.Dairesi'nce, önce 2005/6392 sayı ve 19.01.2006 tarihli kararla yürütmeyi durdurma kararı, sonra da 2007/948 sayı ve 13.03.2007 tarihli kararla iptal kararı verilmiştir.

Yönetmelikte söz konusu 8/a maddesindeki ifadeyle aynı doğrultudaki 30.maddenin 1.fikrasındaki: 'Haklarında gıyabi tutuklama veya tutuklama kararı ile yakalama emri veya zorla getirme kararı bulunan kişilerin yakalanması için yapılacak aramalarda, ayrıca arama kararı verilmesi gerekli değildir. Bu gibi hallerde sadece yakalanacak kişiyle ilişkili işlemler yapılabilir. O yerde bulunan diğer kişiler hakkında ayrıca karar verilmemişse, arama yapılamaz." hükmü de yine aynı kararla çok haklı olarak iptal edilmiştir. Danıştay 10.Dairesi çok yerinde bir değerlendirmeyle, Yönetmeliğin 30/1.maddesindeki bu düzenlemeyle, Yönetmeliğin 8/a maddesine göre kapsamın, yakalanacak kişiye ait olmayan yerlerde yapılacak aramaları da kapsayacak şekilde genişletildiğini de ifade etmiştir.

Danıştay 10.Dairesi ayrıca, bir kişinin Anayasa'nın kişi özgürlüğü ve güvenliği hakkın ${ }^{10}$ düzenleyen 19.maddesinde sayllan nedenlere bağlı olarak, zorla getirilmek, yakalanmak, tutuklanmak suretiyle kişi özgürlüğünün kısıtlanmasının, Anayasa'nın 20. ve 21. maddelerinde düzenlenen özel yaşamın gizliliği ve konut dokunulmazlı̆̆ kendiliğinden kısıtlanması sonucunu doğurmayacağını, 'Bir kişinin,

${ }^{10} \mathrm{Bu}$ konuda Bkz. Serap Keskin, 'Kişi Özgürlüğ̈̈ ve Güvenliği Hakkl' iç. İnsan Hakları, Cogito Yapı Kredi Yayınları İstanbul, Aralık 2000, s.64-97 ve Serap Keskin, 'Kişi Özgürlü̆̈̈̈ ve Güvenliği Hakkına İlişkin Anayasal Değişiklikler', İstanbul Üniversitesi Hukuk Fakültesi Mecmuas1, 2002, C.LX/1-2, s.49-61. 
Anayasada sayılan sebeplere bağlı olarak hürriyetinin kısıtlanması, bu kişinin, Anayasanin 20 ve 21. maddesi ile güvence altına alınan haklardan ve bu haklarla ilgili güvencelerden mahrum edilebileceği anlamına gelmemektedir." cümlesiyle çok güzel ifade etmiştir.

Danıştay 10.Dairesi söz konusu iptal kararında haklı olarak hakkında tutuklama kararı veya yakalama emri veya zorla getirme kararı bulunan kişi ile hakkında gıyabi tutuklama kararı bulunan kaçak hakkında CMK.'da aramaya dair özel düzenleme bulunmadığı saptamasıyla, bunlar hakkında da aramaya dair genel hükmün uygulanacağı sonucuna varmıştır. Aynı kararda yine çok yerinde olarak, gece arama yapılabilecek istisnaların, (CMK.md.118/2) arama kararı açısından da istisnayı oluşturmadığı saptanmıştır. Gece arama yapılabilecek olması, bu arama açısından karar veya emir aranmadığı sonucunu çıkarmaz. Aksinin kabulü için, hukuka uygun yasal düzenleme gerekir. Böyle bir düzenleme de yoktur.

$\mathrm{Bu}$ nedenlerle Yönetmeliğin 8/a maddesindeki kişinin yakalanması amacıyla konutunda, işyerinde, yerleşim yerinde, bunların eklentilerinde ve aracında yapılacak arama ile 30/1.maddesindeki şüpheli veya sanığın yakalanması amaciyla genel bir ifadeyle kimin olursa olsun kişilerin konut, işyeri ve eklentilerinde yapılacak aramalarda, yargıç kararı ve savcının yazılı emri ile sağlanan güvenceyi zedeleyerek, hakkın özünü ortadan kaldıracak biçimde kolluk güçlerine sınırsız arama yetkisi verilmesi nedeniyle söz konusu hükümler, Anayasa ve Yasa'ya aykırı düştüğünden iptal edilmiştir.

$\mathrm{Bu}$ noktada Yönetmeliğin 30.maddesinin 8.fikrasındaki “, Bulundurulması suç teşkil eden eşyanın arandı̆̆ evde bulunan kişilerin üstü, güvenlik veya suç eşyasının elde edilmesi amactyla aranır. " hükmü de dikkati çekmektedir. Kanımca, bu cümledeki '...veya suç eşyasının elde edilmesi... ' ifadesi de CMK.'na aykırıdır. CMK.'nun 90/4.maddesi yalnızca güvenlik amaçlı üst aramasında karar veya emir aranmamasının yasal dayanağını oluşturur. $\mathrm{Bu}$ bakımdan delil amaçlı üst aramasında ayrıca yasal düzenlemeye gerek vardır. 
bb) Hakim kararı veya Cumhuriyet Savcısının yazılı emri ile veya kolluk tarafından doğrudan yakalanan kişinin, kendisine, başkalarına veya yakalama işlemini yapan kolluk görevlilerine zarar vermesini önlemek amacıyla yapılacak kaba üst aramasında karar veya yazılı emir gerekmez.(Yön.md.8/b)

Burada da söz konusu olan, yukarıda olduğu gibi zorunluluk durumundan kaynaklı önlem amaçlı üst aramasıdır ve CMK.'nun 90/4.maddesi çerçevesinde hukuka uygun bir Yönetmelik hükmüdür.

bc)Gözaltına alınan kişinin, nezarethaneye konmadan önce yapılan üst aramasında karar veya yazılı emir gerekmez.(Yön.md.8/c)

Burada da CMK.90/4. madde çerçevesinde hukuka uygun bir üst aramas1 düzenlemesi bulunmaktadır. Yönetmeliğin bu hükmü de Danıştay 10.Dairesi'nin önüne götürülmüş ve düzenleme hukuka aykırı bulunmamiştır.

bd) Herhangi bir sebeple hukuka uygun şekilde yakalandıktan sonra kolluk güçlerinin elinden kaçmakta olan kişilerin veya işlenmekte olan veya henüz işlenmiş olan veya pek az önce işlendiğini gösteren belirtilerin olduğu suçun failinin yakalanması amacıyla takibi sırasında girdikleri araç, bina ve eklentilerinde yakalanması amaciyla yapılacak aramalarda karar veya emir gerekmez.(Yön.md.8/d)

$\mathrm{Bu}$ düzenlemede arama işleminin yapılacağ 1 araç, bina ve eklentilerinin kimin olduğunun önemi yoktur. Diğer deyişle üçüncü kişi nezdinde de, kolluk güçlerinin elinden kaçmakta olan veya suçüstü durumundaki failin yakalanması amaciyla karar veya yazılı emir aranmaksızın arama işleminin yapılabileceği hüküm altına alınmıştır. Madde hükmü bu şekliyle diğer kişiler nezdinde arama işleminin maddi koşullarını düzenleyen CMK.'nun 117.maddesine uygundur.

Yukarıda ilgili başlık altında açıkladığımız gibi, kural olarak şüpheli veya sanık konumunda bulunmayan üçüncü kişide arama koruma tedbirine başvurulabilmesi için makul şüpheyi aşan, aranan şüpheli veya sanığın ya da aranan delilin/delillerin bu kişi nezdinde ele geçirilebileceği 
düşüncesini haklı gösterebilen yeterli şüpheyi temellendiren somut bulguların varlığı gerekir.

$\mathrm{Bu}$ kuralın tek istisnası yakalama aramasında şüphelinin veya sanığın bulunduğu yerler ile izlendiği sırada girdiği yerler hakkındaki aramadadır. Olayın akışına göre gerçekleşen bu gibi durumlarda ayrıca şüphelinin veya sanığın bu yerlerde bulunduğunun kabul edilebilmesine olanak sağlayan olaylara gerek yoktur. Yönetmeliğin $8 /$ d maddesindeki düzenleme de CMK.'nun 117/3.maddesinde yer alan "'Bu sinırlama, şüphelinin veya sanığın bulunduğu yerler ile izlendiği sırada girdiği yerler hakkında geçerli değildir' ' hükmüyle örtüşmektedir.

Ancak CMK.'nda, bu durumda arama kararı veya yazılı emir aranmayacağına dair özel bir düzenleme yoktur. CMK.'nda arama kararı veya yazılı emir olmaksızın arama yapabilmeye dair tek norm üst aramasiyla ilgili olarak CMK.'nun 90/4.maddesinde bulunmaktadır. Bu nedenle Yönetmelikte üst araması dışında eşyada, konutta, işyerinde ve diğer kapalı yerlerde arama işleminde karar veya emir aramayan tüm düzenlemeler, kanuna aykırılı̆̆ nedeniyle hukuka aykırıdır.

Danıştay 10.Dairesi'nin, Yönetmeliğin dava edilen 8/a maddesindeki ifadeyi ve Yönetmeliğin 30/1. maddesini iptal gerekçesi aynen bu düzenleme için de geçerlidir.

Yönetmeliğin 8/d maddesindeki bu hükümden başka, Yönetmeliğin, "Aramanın Zamanı" başıı̆ı̆ı taşıyan 31.maddesi, CMK.'nun 118.maddesine uygun şekilde adli aramanın kural olarak gündüz yapılacağ1 ve yine CMK.'nun 118/1. maddesine uygun şekilde, konutta, işyerinde veya diğer kapalı yerlerde adli aramanın gece yapılamayacağ 1 hükmünü taşımaktadır. Yönetmeliğin 31. maddesi yine CMK.'na uygun olarak, bu yerlerde kolluk amirinin yazilı emriyle arama yapılamayacağını belirtmektedir. Fakat maddede bu cümleden sonra 'Ancak; a) suçüstü halinde, b) gecikmesinde sakınca bulunan halde, c) firar eden kişi veya tutuklu veya hükümlünün tekrar yakalanması halinde, d) geceleyin herkesin girip çıkabileceği 2559 sayll Polis Vazife ve Salahiyet Kanununun 7.maddesinde saylan umuma açı istirahat ve eğlence yerlerinde, gece adli arama yapılabilir' hükmü gelmektedir. 
Bu hükümden anlaşılan, Yönetmeliğin 8/d maddesine paralel olarak söz konusu ayrık gece adli arama yapılabilecek hallerde, arama kararı veya yazılı emrin aranmayacağ yapılabilecek durumlarda kolluk amirinin de evleviyetle arama emri verebileceğidir.

$\mathrm{Bu}$ nedenle kanaatimizce Yönetmeliğin 8/d maddesi yanında 31.maddesindeki bu düzenleme de CMK.'na uygun düşmemektedir ve dolayısıyla hukuka aykırıdır.

CMK.'nun 117/3.maddesindeki ''Bu sinırlama, şüphelinin veya saniğın bulunduğu yerler ile izlendiği sirada girdiği yerler hakkinda geçerli değildir" hükmü, üçüncü kişi nezdinde arama yapabilmenin maddi koşullarıyla ilgili bir hükümdür ve bu durumda CMK.'nun 119.maddesine göre arama kararı veya yazılı emir koşulunu ortadan kaldıran bir hüküm değildir.

Aynı şekilde CMK.'nun 118/2.maddesinde gösterilen gece arama yapmama kuralının istisnaları, Danıştay 10.Dairesi'nin yukarıda değinilen kararında da belirtildiği üzere arama kararı veya yazılı emri açısından da istisnayı oluşturmaz. Gece arama yapılabilecek olması, bu arama açısından karar veya emir aranmadığı sonucunu çıkarmaz. Aksinin kabulü için, hukuka uygun yasal düzenleme gerekir. Böyle bir düzenleme de yoktur.

$\mathrm{Bu}$ nedenlerle Yönetmeliğin 8/d maddesi ile Yönetmeliğin 31.maddesinin 3.fikrasının "Ancak..." kelimesiyle başlayan 3.cümlesi de hukuka aykırıdır.

Fakat somut olayda, gerek kişinin takibi sırasında girdiği, gerekse suçüstü halinde bulunduğu konut, işyeri ve diğer kapalı alanlarda, bu yerlerde bulunan diğer kişiler açısından üçüncü kişi yararına haklı savunmanın koşulları varsa, bu takdirde içeri girip, kişileri kurtarmak için yargıç kararı veya yazılı emir aranmayacağı kuşkusuzdur. Hatta bu durumdaki kişileri kurtarmak için kolluk görevlisi olmak da koşul değildir. Üçüncü kişi yararına haklı savunma hukuka uygunluk nedenidir. Zaten bu özel durum Yönetmeliğin 8/f bendinde ayrıca düzenlenmiştir. 


\section{be)Kaçakçılıkla Mücadele Kanunu'na göre karar veya yazılı emrin aranmayacağı durumlar.(Yön.md.8/e)}

Yönetmeliğin 8.maddesi "e"' bendinde her ne kadar 4926 sayılı Kaçakçıllkla Mücadele Kanunu'na göndermede bulunulmuşsa da bugün pozitif hukukta 10.7.2003 tarihli ve 4926 sayılı Kaçakçılıkla Mücadele Kanunu'nun yerine 21.3.2007 tarih ve 5607 sayılı Kaçakçılıkla Mücadele Kanunu vardır. 5607 sayılı ve 21.03.2007 tarihli Kaçakçılıkla Mücadele Kanunu öncekini yürürlükten kaldırmıştır.(md.25)

5607 sayılı Kaçakçılıkla Mücadele Kanunu, Geçici 1.maddesiyle ' 'Diğer kanunlarda mülga 7/1/1932 tarihli ve 1918 sayılı Kaçakçıllğın Men ve Takibine Dair Kanun ile bu Kanunla yürürlükten kaldirllan Kaçakçılıkla Mücadele Kanununa yapılan atıflar, bu Kanuna yapılmış sayılır." hükmünü getirmiştir. Dolayısıyla, Adli ve Önleme Aramaları Yönetmeliği'nin 8/e maddesinde, 4926 sayılı Kanuna yapılan göndermeler, 5607 sayılı Kanuna yapılmış sayılacaktır.

Bu nedenle Yönetmeliğin 8/e,1. maddesinde yürürlükten kaldırılmış olan 4926 sayılı Kanunun 17.maddesinin ikinci fikrası kapsamında, kaçak eşya, her türlü silah, mühimmat, patlayıcı ve uyuşturucu maddelerin bulunduğu şüphe edilen her türlü kap, ambalaj veya taşımaya yarayan diğer araçlarda hemen yapılan aramalarda karar veya emir alınmadan arama yapılabileceğine dair düzenlemenin de uygulanabilme olanağ 1 kalmamıştır.

Çünkü bizzat 21.3.2007 tarihli ve 5607 sayılı yürürlükteki Kaçakçılıkla Mücadele Kanunu'nun arama ve elkoymayı düzenleyen 9.maddesi 1.fikrasında, söz konusu durumda yapılacak arama ve elkoymalarda 5271 sayılı CMK.'nun uygulanacağı hükmünü amirdir. ${ }^{11}$ Dolayısıyla bu durum artık istisnayı oluşturmamaktadır.

Yönetmeliğin 8/e,2.maddesindeki '4926 sayılı Kaçakçılıkla Mücadele Kanununun 17nci maddesinin altınc1 fikrası kapsamında

\footnotetext{
${ }^{11}$ ARAMA VE ELKOYMA

Madde 9- (1) Kaçak eşya, her türlü silah, mühimmat, patlayıcı ve uyuşturucu maddelerin bulunduğundan şüphe edilen her türlü kap, ambalaj veya taşımaya yarayan diğer araçlar ile kişilerin üzerlerinde yapılacak arama ve elkoymalar, 4/12/2004 tarihli ve 5271 sayılı Ceza Muhakemesi Kanunu uyarınca yerine getirilir.
} 
gümrük salonları ve gümrük kapılarında kaçak eşya sakladığından kuşkulanılan kişilerin gümrük kontrolü amacıyla gümrük görevlilerince aranmasında' karar veya emir alınmadan arama yapılabileceğine dair düzenleme, 5607 sayılı Kaçakçılıkla Mücadele Kanunu'na da uygundur. $\mathrm{Bu}$ nedenle 4926 sayılı Kanunun 17/6.maddesine yapılmış gönderme, 5607 sayılı Kanunun 9/2.maddesine yapılmış sayılacaktır. ${ }^{12}$

Yönetmeliğin 8/e,3.maddesindeki 4926 sayılı Kaçakçılıkla Mücadele Kanununun 18.maddesinin ikinci fikrası kapsamında, Gümrük Kanunu gereğince belirlenen kapı ve yollardan başka yerlerden gümrük bölgesine girmek, çıkmak veya geçmek ve bu yerlerde rastlanacak kişi ve her nevi taşıma araçlarının yetkili memurlar tarafından durdurulmasında ve bu kişilerin eşya, yük ve üzerleri ile varsa taşıma araçlarının aranmasında", karar veya emir alınmadan arama yapılabileceğine dair düzenleme, 5607 sayılı Kaçakçılıkla Mücadele Kanunu'na da uygundur. Bu nedenle 4926 sayılı Kanunun 17/6.maddesine yapılmış gönderme, 5607 sayılı Kanunun 9/3.maddesine yapılmış sayılacaktır. ${ }^{13}$

\section{bf) Hukuka uygunluk nedenlerinin varlığında karar veya emir gerekmez.(Yön.md.8/f)}

Yönetmeliğin 8/f maddesinde, 5237 sayılı Türk Ceza Kanunu'nun 24 üncü maddesindeki kanunun hükmü ve amirin emrini yerine getirme, 25 inci maddesindeki meşru savunma ve zorunluluk hali ve $26 \mathrm{nc}$ maddesindeki hakkın kullanılması ve diğer kanunların öngördüğü hukuka uygunluk sebepleri ve suçüstü halinde yapılan aramalarda, toplum için veya kişiler bakımından hayatî tehlikeyi ortadan kaldırmak amacıyla veya kapalı yerlerden gelen yardım çağrıları üzerine, konut, işyeri ve yerleşim yeri ile eklentilerine girmek için arama veya yazılı emir gerekmez.

\footnotetext{
${ }^{12}$ ARAMA VE ELKOYMA

Madde 9-...(2) Gümrük salonları ve gümrük kapılarında kaçak eşya sakladığından kuşkulanılan kişilerin üzeri, eşyası, yükleri ve araçları gümrük kontrolü amacıyla gümrük görevlilerince aranabilir. Yapılan arama sonucunda tespit edilen kaçak eşyaya derhal elkonulur.

${ }^{13}$ ARAMA VE ELKOYMA

Madde 9-...(3) Gümrük bölgesine, Gümrük Kanunu gereğince belirlenen kap1 ve yollardan başka yerlerden girmek, çıkmak veya geçmek yasaktır. Bu yerlerde rastlanacak kişi ve her nevi taşıma araçları yetkili memurlar tarafından durdurulur ve kişilerin eşya, yük ve üzerleri ile varsa taşıma araçları aranır. Yapılan arama sonucunda tespit edilen kaçak eşyaya derhal elkonulur.
} 
Yönetmeliğin 8/f maddesindeki "'ilgilinin rızası" ibaresi de Danıştay 10.Dairesinin yukarıda değinilen kararıyla iptal edilmiştir. Kanaatimizce aramaya tabi olan kişinin rızası, bireyin devlet gücüyle karşı karşıya geldiği gerçekliğinde arama koruma tedbiri açısından bir hukuka uygunluk nedeni olarak kabul edilemez. ${ }^{14}$ Burada devlet gücüyle karşı karşıya kalan bireyin, maddi-manevi her türlü baskıdan arık özgür iradeyle rıza göstermesi genel gerçeklikle bağdaşmaz. Aramada rızanın hukuka uygunluğu 24.5.2003 tarihli Resmi Gazete'de yayınlanarak yürürlüğe girmiş olan önceki Adli ve Önleme Aramaları Yönetmeliği'nin 9.maddesinde de kabul edilmişti. Söz konusu 9.madde rıza ile arama başlığını taşımaktaydı. Bu hükme paralel olarak aynı Yönetmeliğin 20/2.maddesinde de "9. madde gereğince riza ile yapılacak aramada, memur önce aramanın amacın bildirir, izin verme yetkisine sahip kişiye rıza göstermeye mecbur olmadı̆̆ını söyler ve izin verme yetkisine sahip olan kişinin rızasını saptar. Ancak bu kissiyi, el konulan eşyanın delil olarak kullanılabileceği hususunda bilgilendirir. Aramanın ne sifatla yapıldı̆̆g, arama yapılan kişiye bildirilir. " hükmü vardı.

Danıştay 10.Dairesi, İzmir Barosu'nun başvurusu üzerine her iki düzenlemeyi de 11.11.2003 tarihli kararıyla iptal etmişti. Danıştay'ın iptal gerekçesi şuydu: "Anayasa'nın sikı bir şekilde korumakla yetinmeyip, sinırlama ölçütlerini de sikı kurallara bağladı̆̆ temel haklardan olan 'özel hayatın gizliliği' ve 'konut dokunulmazlığı' hakkından tümüyle vazgeçilmesi anlamına gelen 'rıza ile arama' müessesesinin, bu hakların ihlalini kolaylaştıracağ ve Anayasa ile getirilen korumayı işlevsiz hale getireceği açıktır."

Bu kez, halen yürürlükte bulunan 01.06.2005 tarihli Adli ve Önleme Aramaları Yönetmeliği 8/f bendinde, diğer hukuka uygunluk nedenleri yanında artık yeni TCK.'da 26/2.maddede normatif bir yapıya kavuşan mağdurun rızası hukuka uygunluk nedenine dayanarak ve bu hukuka uygunluk nedenini önceki Yönetmelikte olduğu gibi diğerlerinden ayırmayarak, arama kararı veya emri olmaksızın arama yapmada bir hukuka uygunluk nedeni olarak kabul etmiştir.

\footnotetext{
${ }^{14}$ Aynı görüşte, Faruk Turhan, age. s.242.
} 
Söz konusu düzenlemedeki "'ilgilinin rızası" ibaresi İstanbul Baro'sunun açtığı dava sonucunda Danıştay 10.Dairesince yukarıda da değinilen 13.03.2007 tarih ve 2007/948 sayılı karar ile iptal edilmiştir. Danıştay 10.Dairesi önceki iptal gerekçesiyle aynı doğrultuda, Anayasa'nın özel hayatın gizliliği ve konut dokunulmazlığı hakkını düzenleyen 20. ve 21.maddelerinde sinırlama usulleri içinde "'ilgilinin rızasına" yer verilmediği haklı saptamasını yaptıktan sonra, "...gerek Anayasa'nın ilgili maddelerinde, gerek 5271 sayll Yasada, özel hayatın gizliliği ve konut dokunulmazlığı hakkı ile kamu güvenliği arasında bir denge kurulmaya çalışllırken, birey ile kolluk arasındaki güç dengesizliğinin, ilgilinin rıasını sakatlayabileceği endişesiyle, bu hakların, mümkün olduğunca yargl yerlerince verilen kararlarla sınırlanması esası benimsenmiştir. Anayasanın sıkı bir şekilde korumakla yetinmeyip, sınırlama ölçütleri de sikı kurallara bağladı̆̆ temel haklardan olan özel hayatın gizliliği ve konut dokunulmazlığ hakkından tümüyle vazgeçilmesi anlamina gelen rıza müessesesinin, bu hakların ihlalini kolaylaştıracağı ve Anayasa ile getirilen korumayı işlevsiz kılabileceği açıktır." gerekçesiyle iptal kararı vermiştir. Bu gerekçe, insan haklarına dayalı hukuk devleti bakımından örnek bir gerekçedir.

bg)Suçun işlendiği kamuya açık alanda olay yeri incelemesi için karar veya emir gerekmez.(Yön.md.9)

Konutta, işyerinde ve kamuya açık olmayan kapalı alanlarda arama işlemi yapabilmek için yargıç kararı veya gecikmesinde sakınca bulunan hallerde Cumhuriyet Savcısının yazılı emri koşuldur. Gecikmede sakınca durumunda Cumhuriyet Savcısına ulaşılamayan halde kamuya açık olan kapalı alanlarda kolluk amirinin yazılı emri ile de arama işlemi gerçekleştirilebilecektir. Ancak kamuya açık olan yer herkesin girip çıkabileceği bir yer ise karar veya emir gerekli değildir. Kanaatimizce "herkesin girip çıkabileceği kamuya açık yer" kavramı ancak genel yerleri (umumi yer) kapsar.

Suçun işlendiği yer herkesin girip çıkabileceği kamuya açık yerlerden ise, burada gerek kriminalistik biliminin yöntemleriyle gerekse doğrudan doğruya delil araması yapabilmek, diğer deyişle olay yeri incelemesi yapabilmek için yargıç kararına veya Cumhuriyet Savcısının ya da kolluk amirinin yazılı emrine gerek yoktur. 'Kriminalistik, suç 
olayını maddi gerçeğe uygun olarak araştıran ve ortaya koyan bir bilim dalıdır. ${ }^{15}$ Kriminalistik biliminin yöntemleriyle gözle görülen veya görülemeyen ispat değeri taşıyan bulgular ortaya çıkarılır.

Yönetmelik bu hususu, "'suç işlenen yerlerde, sebep ve sonuç ilişkisini ortaya koyacak delillerin aranması, bulunmast ve el koyulması için geliş̧tirilmiş bilimsel ve teknik araştırma işlemlerinin, herkesin girip çıkabileceği kamuya açık alanlarda yapılması için emir veya karar gerekmez" ş̧eklinde ifade etmiştir. Kamuya açık yer herkesin girip çıkabileceği genel bir yer ise karar veya emir aranmaz. Kamuya açık yer, herkesin girip çıkabileceği genel bir yer değilse kolluk amirinin yazılı emri ile de arama işlemi yapıllabilir.

Fakat yukarıdaki çerçeve içinde kamuya açık kapalı alanlarda genele açık olmayan özel kısımlar varsa bu kısımlar da koruma kapsamındadır ve bu noktalarda arama yapabilmek için de karar veya Cumhuriyet Savcısının yazılı emri gerekir.

\section{C- ADLI ARAMANIN ZAMANI}

Konutta, işyerinde veya diğer kapalı yerlerde adli arama, kural olarak gündüz yapılır. Gündüz zamanı, güneş doğmasından bir saat önceden başlayan, güneş batmasından bir saat sonra biten zaman dilimidir. (TCK.md.6/1,e) Arama işleminin gündüz yapılması demek, gündüz başlaması demektir. Gündüz başlanan arama, gece başlayana kadar bitmezse aramaya devam olunur. ${ }^{16}$ Burada uygulamanın yasayı dolanmak amacını taşımaması da gerekir. Her somut olay ayrı değerlendirilir. Ana kuralın istisnaları şunlardır:

a-suçüstü halinde,

b-gecikmesinde sakınca bulunan hallerde,

c-yakalanmış veya gözaltına alınmış olup da firar eden kişi veya

ç-firar eden tutuklu veya hükümlünün tekrar yakalanması amacıyla yapılan aramalarda geceleyin de arama işlemi yapılabilecektir. (CMK.md.118)

\footnotetext{
${ }^{15}$ Öztürk-Erdem, age., s.429.

${ }^{16}$ Kunter/Yenisey/Nuhoğlu, No.59.4,III, s.904.
} 


\section{D- ARAMADA HAZIR BULUNMASI GEREKENLER}

\section{a- Hazır Bulunabilecek Kişiler}

Arama işleminin hukuka uygunluğu için mutlaka bulunmaları gerekmeyen, ancak bu işlem sırasında bulunmayı istedikleri takdirde kendilerine engel de olunamayan kişilerdir. Öncelikle, aranacak yerin sahibi veya eşyanın zilyedi bu hakka sahiptir. Yasa, '. ...aramada hazır bulunabilir..." ifadesiyle zorunluluk olmadığını göstermiştir.(CMK.md.120/1) Söz konusu hakkın kullanılabilmesi için doğal olarak aranacak yerin sahibi veya arama uygulanacak eşyanın zilyedinin bu durumdan haberdar olmaları gerekir. Yasa koyucu söz konusu kişilerin aramaya tabi olacaklarını bilmeme olasılı̆̆ bu kişilere ulaşılamayıp, onların bulunamaması durumunda, temsilcisinin veya ayırt etme gücüne sahip hısımlarından birinin veya kendisiyle birlikte oturmakta olan bir kişinin veya komşusunun hazır bulundurulmasını ise zorunlu tutmuştur. ${ }^{17}(\mathrm{CMK} . \mathrm{md} .120 / 1) \mathrm{Bu}$ kişiler, aram işlemi sırasında gözlemci olarak bulunurlar. ${ }^{18}$

Aynı şekilde kişinin avukatının aramada hazır bulunmasına da engel olunamaz.(CMK.md.120/3)

Üçüncü kişi nezdinde arama işlemi yapılacaksa, zilyede, zilyet bulunamıyorsa yerine çağrilacak kişiye, aramaya başlamadan önce aramanın amaci hakkında bilgi verilmesi yasal zorunluluktur. Aksi, arama işlemini hukuka aykırı hale getirir. ${ }^{19}$

\section{b- Hazır Bulunması Zorunlu Kişiler}

Arama işlemi sırasında kural olarak Cumhuriyet Savcısının hazır bulunması gerekir. Ancak bu husus mutlak bir zorunluluk değildir. Eğer, konutta, işyerinde veya diğer kapalı yerlerde aramada Cumhuriyet Savcısı hazır bulunamıyorsa, arama yapabilmek için o yer ihtiyar heyetinden veya komşulardan iki kişinin bulundurulması yasal zorunluluktur.(CMK.md.119/4) Aksi durumda hem arama işlemi hem de dolayısıyla bu işlemden ele geçirilen deliller hukuka aykırı duruma gelip, hükme esas alınamazlar. (CMK.md.217/2)

\footnotetext{
${ }^{17}$ Kunter/Yenisey/Nuhoğlu, No.59.3; Öztürk-Erdem, s.594

${ }^{18}$ Nur Centel/Hamide Zafer, s.393.

${ }^{19}$ Öztürk-Erdem, s.594.
} 
Yukarıda değinildiği gibi, aranacak yerin sahibi veya eşyanın zilyedi aramada hazır bulunabilir. Ancak, bu kişiler bulunmazsa, temsilcisinin veya ayırt etme gücüne sahip hısımlarından birinin veya kendisiyle birlikte oturmakta olan bir kişinin veya komşusunun arama sırasında hazır bulundurulması zorunludur. ${ }^{20}$ (CMK.md.120/1)

Askeri yerlerde yapılacak arama işlemi, Cumhuriyet Savcısının istem ve katılımıyla askeri makamlar tarafindan yerine getirilir. (CMK.md.119/5)

\section{E- ARAMANIN SONLANDIRILMASI}

Aramanın sonunda hakkında arama işlemi uygulanan kişinin isteği üzerine, şüpheli veya sanık sıfatıyla $\mathrm{m} 1$ yoksa üçüncü kişi sıfatıyla mı aramaya tabi olduğunu ve aynı zamanda aramanın amacının ne olduğunu gösteren bir belge verilir. Şüpheli veya sanık sıfatıyla aramaya tabi olma durumunda ayrıca soruşturma veya kovuşturma konusu fiilin niteliğinin de aynı belge de gösterilmesi zorunludur.

Bundan başka, yine istek üzerine, elkonulan veya koruma altına alınan eşyanın listesini içeren bir defter de aramaya tabi kişiye verilir. Söz konusu eşya resmi mühürle mühürlenir veya bir işaret konulur.(CMK.md.121/3) Elkonulan eşyanın mülkiyetine ilişkin olarak, hakkında arama işlemi uygulanan kişinin görüş ve iddialarına da yer verilir.(CMK.md.121/2)

Arama sonunda, şüpheyi haklı kılan bir şey elde edilmemiş ise bunu belirten bir belge verilir.(CMK.md.121/1)

Hakkında arama işlemi uygulanan kimsenin belge veya kağıtlarını inceleme yetkisi, Cumhuriyet Savcis1 ve yargica aittir.(CMK.md.122/1) 1412 sayılı önceki CMUK. bu yetkiyi yalnızca yargıca vermişken, 5271 sayılı yeni CMK. bu yetkiyi ayrıca Cumhuriyet Savcısına da tanımıştır. Her durumda kolluk amir ve memurlarının belge ve kâğttları inceleme yetkisi yoktur.

Belge ve kâğıtların zilyedi veya temsilcisinin kendi mührünü koyma veya imzasını atma hakkı vardır. İleride mührün kaldırılmasına ve kâğıtların incelenmesine karar verildiğinde bu işlemin yapılmasında hazır

${ }^{20}$ Kunter/Yenisey/Nuhoğlu, No.59.3; Öztürk-Erdem, s.594. 
bulunmak üzere, zilyedi veya temsilcisi ya da müdafii veya vekilinin de çağrılması Yasa gereğidir. Ancak, söz konusu kişilerin çağrıya karşın gelmemeleri incelemenin yapılmasına engel oluşturmaz. (CMK.md.122/2)

Arama kararı veya yazılı emrinin bir örneğinin nezdinde arama işlemi uygulanan kişiye verilmesi zorunluluğunu içeren yasal düzenlemenin olmaması öğretide eksiklik olarak değerlendirilmektedir. ${ }^{21}$ Kanaatimizce de arama kararının veya yazılı emrinin hukuka uygunluğunun denetiminde, bu belgenin ilgili kişiye kural olarak arama işlemine başlamadan önce, zorunluluk durumunda ise arama işleminin sonunda verilmesi hak ve özgürlüğün korunması açısından bir zorunluluktur.

\section{F- KANUNYOLU}

Soruşturma evresinde sulh ceza yargıcının verdiği arama kararına, yargıç kararı olduğundan itiraz yolu açıktır.(CMK.md.267) 5271 sayılı CMK., 267.maddesinde 'kanunun gösterdiği hallerde mahkeme kararlarına karşı itiraz yoluna gidilebilir"' demektedir. Kanun, arama işleminin kovuşturma evresinde de yapılabileceğini kabul etmiş̧ir; ancak kovuşturma evresinde verilebilecek arama kararına karşı, örneğin tutuklamada(CMK:md.101/5), adli kontrolde(CMK:md.111/2) olduğu gibi itiraz yoluna gidilebileceğine dair özel düzenlemeyi burada yapmamıştır. $\mathrm{Bu}$ nedenle, kovuşturma evresinde mahkemece verilen arama kararının hukuka aykırılığını ileri sürebilmek kural olarak hüküm verildikten sonra temyiz aşamasında olabilecektir. Fakat hüküm verilinceye kadar, olağanüstü kanun yolu niteliğindeki kanun yararına bozma (CMK.md.309) yolu da teorik olarak uygulanabilir. ${ }^{22}$

Yazılı emir üzerine arama işleminin, emrin verildiği zamandan itibaren 24 saat içinde, soruşturma evresinde sulh ceza yargıcının, kovuşturma evresinde ise mahkemenin onayına sunulması anayasal zorunluluktur.

\footnotetext{
${ }^{21}$ Recep Gülşen, “Yeni Ceza Muhakemesi Kanunu'nda Arama”, Hukuki Perspektifler Dergisi(HPD), Mart 2005, S.3, s.92.

${ }^{22}$ Aynı görüşte, Recep Gülşen, age. s.93.
} 


\section{KAYNAKÇA}

Nur Centel/Hamide Zafer, Ceza Muhakemesi Hukuku, Beta Basım İstanbul, Ocak 2008, 5.B.

Recep Gülşen, 'YYeni Ceza Muhakemesi Kanunu'nda Arama', Hukuki Perspektifler Dergisi(HPD), Mart 2005, S.3.

Serap Keskin,'Kişi Özgürlüğü ve Güvenliği Hakkı' iç. İnsan Hakları, Cogito Yapı Kredi Yayınları İstanbul, Aralık 2000.

Serap Keskin, 'Kişi Özgürlüğü ve Güvenliği Hakkına İlişkin Anayasal Değişiklikler', İstanbul Üniversitesi Hukuk Fakültesi Mecmuası, 2002, C.LX/1-2, s.49-61.

Nurullah Kunter/Feridun Yenisey/Ayşe Nuhoğlu, Muhakeme Hukuku Dalı Olarak Ceza Muhakemesi Hukuku, Beta Yayınevi İstanbul, 15.Bas1, Kasim 2006.

Bahri Öztürk-Mustafa Ruhan Erdem, Uygulamalı Ceza Muhakemesi Hukuku, Seçkin Yayınevi Ankara,12.Bası, Kasım 2008.

Cumhur Şahin, Ceza Muhakemesi Hukuku I, Seçkin Yayıncılık-Ankara 2007.

Nevzat Toroslu-Metin Feyzioğlu, Ceza Muhakemesi Hukuku, Savaş Yayınları, Ankara 2006.

Faruk Turhan, Ceza Muhakemesi Hukuku, Asil Yayın Dağıtım Ankara 2006. 